\title{
New insights into the mechanism of sulfur vulcanisation: a theoretical study
}

\author{
Iurii Bodachivskyi \\ University of Technology Sydney, School of Mathematical and Physical Sciences, \\ Sydney, NSW 2007, Australia \\ iurii.bodachivskyi@uts.edu.au
}

\begin{abstract}
Sulfur vulcanisation, of alkenes is a widely employed industrial chemical process delivering a range of organic polysulfanes as principal products. Notwithstanding their practical importance, the fundamental understanding of thermally activated vulcanisation without the use of accelerants is available only in restricted sense: it is highly unselective process and there is little knowledge whether the accompanying reactions occur through ionic or free-radical mechanisms. Here, the work details the mechanism of the sulfur vulcanisation under non-accelerated conditions using density functional computations at B3PW91/6-311+G(3d,f) level of theory in a simulated reaction system at the temperature of sulfur polymerisation $(432.15 \mathrm{~K})$. The study starts from the investigation of the homolytic and heterolytic $\mathrm{S}-\mathrm{S}$ bond dissociation of the octasulfur ring and its transformations into other reactive forms. It predicts that the heterolysis is a principal reaction leading to the octasulfur zwitterions, relative to the homolysis into diradicals, as well as that the formation of macrocyclic sulfur derivatives is more likely to take place as opposed to linear analogous products; however, it also demonstrates that disulfur diradicals might favourably form via pseudoreversible decomposition of macrocyclic sulfur into the initial eight-membered ring form. This work also analyses model reactions between sulfur and cis-2-butene via addition to double bonds or through the substitution of allyl hydrogens identifying preferred reaction pathways. Possibly, the addition products are generated from the reaction of the alkene and the octasulfur through the formation of zwitterions. Alternatively, disulfur diradicals may substitute allyl hydrogens forming hydrodisulfanes that further convert into polysulfanes by the addition to double bonds or by the oxidation with molecular oxygen.
\end{abstract}

Keywords: elemental sulfur, alkenes, vulcanisation, reaction mechanisms

\section{Introduction}

The current petrochemical industry leaves a bulk of unused materials and their valorisation into functional products is a topical subject for sustainable industrial chemistry. In particular, desulfurisation processes and reduction of sulfur dioxide emissions annually generate more than 60 million tons of elemental sulfur, among which ca. 7 million tons remains unexploited [1]. Sulfuration of alkenes with elemental sulfur, often referred to as sulfur vulcanisation, is a promising way to obtain value added organic polysulfanes (OPs) [2]. Historically, OPs with a molecular formula $\mathrm{R}-n \mathrm{~S}-\mathrm{R}(\mathrm{R}=$ organyl, $n>1)$ have been effectively employed in manufacturing of synthetic rubbers, lubricants and chemically resistant concretes, as well as more recently in the production of nanomaterials for optical and energy devices [2-7]. In many instances, the use of polysulfanes has significantly advantaged performance and ecological properties of the end products, relative to existing analogous, pleasingly complying with sustainability requirements. For example, sulfurated fatty acid derivatives were found to possess improved operating properties and biodegradability in various lubricating systems [3-5], while OPs- based cathode materials were noted to enhance the efficiency of lithium- and sodium-sulfur batteries [1,7]. Considering the available scale of elemental sulfur, along with manifold applications of OPs, the development of sulfuration chemistry is a topic of significant current scientific and commercial interest.

Despite practical advancement towards deployment of polysulfanes in extant commercial settings, the fundamental understanding of sulfur vulcanisation remains debatable for different reasons. In the first, it relates to the complexity of sulfur chemistry under applied processing temperatures $\left(120-220^{\circ} \mathrm{C}\right)$ that typically involves the formation of numerous reactive sulfur species, including linear and (macro)cyclic derivatives (usually regarded as $S_{8}, S_{\pi}, S_{\mu}$ or $S_{\infty}$ ) $[2,8]$. In the second, alkene substrates can react with sulfur intermediates via addition to double bonds or through the substitution of allyl hydrogens (hydrogens in the $\alpha$-position near the double bond), ultimately producing a range of OPs [2-5]. Sometimes the processes can be promoted by the addition of reactive catalysts (accelerants) that typically participate in chemical transformations and which are frequently consumed during the processing thereof $[9,10]$. The 
core of long-lasting debates remains the nature of the sulfuration mechanism. In their seminal study [11], Farmer and Shipley proposed that sulfur forms diradicals reacting with alkenes. As opposed to this proposal, Ross [12], and independently Bateman and colleagues [13], suggested that sulfuration is a polar chain reaction, especially in the presence of accelerators. Since then, scientific and technical literature has evidenced the reliance on both interpretations that are summarised and discussed in several reviews $[2,14]$. Although there has been some progress in structural elucidation of sulfuration products uncovering potential reaction pathways $[3,5,10]$, and one elegant mechanistic study providing details of zinc(II)-dithiocarbamateaccelerated vulcanisation [15], a general conclusion whether the process occurs via free-radical or polar mechanism has not been made; this especially relates to the thermally activated processes without a use of accelerators. This work addresses this issue.

The present study shows a theoretical research detailing the mechanism of the non-accelerated sulfuration by molecular modelling of potential reactions of sulfur and cis-2butene. Note that the aim of this study is not to fully decipher vulcanisation process, but rather to analyse principal reaction pathways involved into the formation of OPs. This is to highlight the complexity of the chemistry and to discourage further simplification or misinterpretations in literature.

\section{Theoretical methods}

Density functional computations were conducted employing Gaussian 09 software [16]. Geometry optimisation for potential sulfur species and polysulfanes were performed using hybrid B3PW91 functional and the basis set $6-311+G(3 d, f)$. This level of theory was shown to be optimal for varied sulfur-rich molecules, adequately correlating with experimental data $[17,18]$. Predictions of thermochemical properties were performed in a simulated system at $432.15 \mathrm{~K}$ (temperature of sulfur polymerisation [8]) and pressure of $101.325 \mathrm{kPa}$. Cis-2-butene was exploited as a simple alkene for sulfuration reactions to minimise the expenses underpinning the computation time. The possibility of one or another reaction pathway was evaluated based on its enthalpy of activation $\left(\Delta E, \mathrm{~kJ} \mathrm{~mol}^{-1}\right)$ under specified conditions $(432.15 \mathrm{~K}, 101.325 \mathrm{kPa})$.

\section{Results and discussion}

Sulfur predominantly exists as a stable eight-member cycle $S_{8}$ at moderate temperatures, and tends to alter its molecular formula and structure under more forcing conditions. It becomes somewhat reactive during the cleavage of the cyclic structure at temperatures above $159^{\circ} \mathrm{C}(432.15 \mathrm{~K})$, often regarded as sulfur 'polymerisation temperature' or 'transition temperature' [8]. In vulcanisation chemistry, it is generally accepted that reactions with alkenes occur during the homolytic or heterolytic dissociation of $S_{8}$ into respective linear diradicals or zwitterions that further defines the mechanism of the process $[2,14]$. To detail the S-S bond dissociation of the octasulfur, the formation of the openring sulfur in a singlet and triplet states was researched. The singlet state corresponds to the sulfur zwitterions, while the triplet state correlates with the sulfur diradicals. Among defined stable open-ring species, one zwitterion was substantially more stable than other derivatives (Figure 1a), implying that heterolysis is more likely to take place. Despite these results, earlier ESR studies reported the formation of diradicals in sulfur melts in small concentrations, and there is a good correlation between experimental and theoretical $\Delta E$ values (Figure 1a; $\Delta E$ ca. $150 \mathrm{~kJ} \mathrm{~mol}^{-1}$ ); however, ESR methods generally permit observation of materials with unpaired electrons, such as radicals, and cannot define species with paired electrons, such as zwitterions. It is therefore suggested that both types of S-S bond dissociation (homolytic and heterolytic) are possible, even though the occurrence of the stable zwitter-ion remains to confirm experimentally. Besides thermodynamic values, the geometry optimisation of the open-ring sulfur uncovered significant changes to $\mathrm{S}-\mathrm{S}$ bond lengths, relative to the initial octasulfur. In the cyclic form, all S-S bonds are ca. $2.06 \AA$. For the open-ring species, these bonds are not equal and consecutively vary after every two atoms from 1.91-1.99 $\AA$ to 2.10-2.25 $\AA$ (Figure 1b). This apparent changes to the bonding patterns may serve as reactive centres for further conversion of $S_{8}$ into other reactive forms. (a)

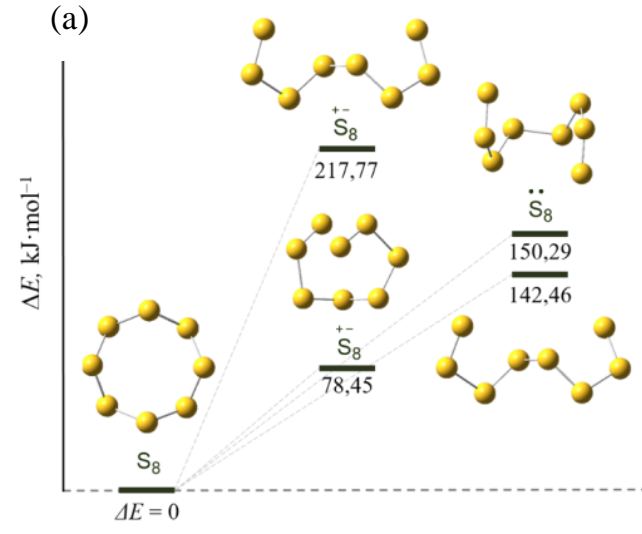

(b)

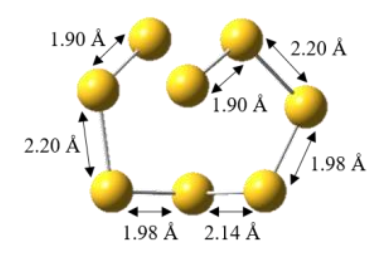

Fig. 1. Energy diagram for the thermal dissociation of the cyclic octasulfur (a) and the structure of the intermediate zwitterion (b) 


\begin{tabular}{|c|c|c|c|c|c|}
\hline$\widehat{S}_{8} \rightleftarrows 4 \mathrm{~S}_{2}$ & $\Delta E=746,60$ & (1) & $\mathrm{S}_{8} \rightleftarrows 8 / 7 \mathrm{~S}_{7}$ & $\Delta E=34,55$ & (13) \\
\hline$\widehat{S}_{8} \rightleftarrows 8 / 3 \mathrm{~S}_{3}$ & $\Delta E=284,04$ & (2) & $\widehat{S}_{8} \rightleftarrows 8 / 9 \widehat{S}_{9}$ & $\Delta E=30,46$ & (14) \\
\hline $\mathrm{S}_{8} \rightleftarrows 2 \mathrm{~S}_{4}$ & $\Delta E=276,81$ & (3) & $\mathrm{S}_{8} \rightleftarrows 4 / 5 \mathrm{~S}_{10}$ & $\Delta E=28,50$ & (15) \\
\hline $\mathrm{S}_{8} \rightleftarrows 8 / 5 \stackrel{+-}{\mathrm{S}_{5}}$ & $\Delta E=264,36$ & (4) & $\widehat{S}_{8} \rightleftharpoons 8 / 11 S_{11}$ & $\Delta E=44,33$ & (16) \\
\hline$\widehat{S}_{8} \rightleftarrows 4 \ddot{\mathrm{s}}_{2}$ & $\Delta E=348,22$ & (5) & $\widehat{S}_{8} \rightleftarrows 2 / 3 \mathrm{~S}_{12}$ & $\Delta E=32,30$ & (17) \\
\hline$\widehat{S}_{8} \rightleftarrows 8 / 3 \ddot{s}_{3}$ & $\Delta E=479,16$ & (6) & $\widehat{S}_{8} \rightleftarrows 8 / 13 \mathrm{~S}_{13}$ & $\Delta E=23,40$ & (18) \\
\hline$\widehat{S}_{8} \rightleftarrows 2 \ddot{\mathrm{S}}_{4}$ & $\Delta E=278,88$ & (7) & $\widehat{S}_{8} \rightleftarrows 4 / 7 \mathrm{~S}_{14}$ & $\Delta E=15,45$ & (19) \\
\hline$\widehat{S}_{8} \rightleftarrows 8 / 5 \ddot{\mathrm{S}}_{5}$ & $\Delta E=233,39$ & (8) & $\widehat{S}_{8} \rightleftarrows 8 / 15 \widehat{S}_{15}$ & $\Delta E=34,39$ & (20) \\
\hline $\mathrm{S}_{8} \rightleftarrows 8 / 3 \mathrm{~S}_{3}$ & $\Delta E=359,79$ & (9) & $\mathrm{S}_{8} \rightleftarrows 1 / 2 \mathrm{~S}_{16}$ & $\Delta E=57,45$ & (21) \\
\hline$\widehat{S}_{8} \rightleftarrows 2 \mathrm{~S}_{4}$ & $\Delta E=367,14$ & (10) & $\widehat{s}_{10} \rightleftarrows \ddot{s}_{2}+\widehat{s}_{8}$ & $\Delta E=51,43$ & (22) \\
\hline$\widehat{S}_{8} \rightleftarrows 8 / 5 \mathrm{~S}_{5}$ & $\Delta E=113,84$ & (11) & $\Omega_{S_{6}}+\Omega_{12} \rightleftarrows \ddot{s}_{2}+2 S_{8}$ & $\Delta E=5,30$ & (23) \\
\hline$\widehat{S}_{8} \rightleftarrows 4 / 3 \mathrm{~S}_{6}$ & $\Delta E=44,40$ & (12) & & & \\
\hline
\end{tabular}

Scheme 1. Proposed transformations of the cyclic octasulfur into other sulfur forms

The analyses of transformations of sulfur into other possible species (in this work, the formation of $S_{2}-S_{16}$ derivatives was assessed) showed that the production of high molecular weight cyclic $\mathrm{S}_{6}-\mathrm{S}_{16}$ molecules is thermodynamically more possible than low molecular weight open-ring derivatives (Scheme 1, equations 121). Moreover, the optimisation of high molecular weight sulfur (more than 8 sulfur atoms) as linear radicals or zwitterions was persistently accompanied by the ring closure. This highlights the greater stability of the macrocyclic sulfur, compared to analogous open-ring structures. Earlier experimental works demonstrate that the transformation of the octasulfur into other forms is a slow process and that high molecular weight products tend to rapidly decompose into $\mathrm{S}_{8}$ [8]. The current theoretical predictions suggest that these may occur with the formation of the disulfur diradical as a byproduct of the pseudoreversible conversion into cyclic $\mathrm{S}_{8}$ (Scheme 1, equations 22 and 23). The cause for this may be anomalous changes to $\mathrm{S}-\mathrm{S}$ bond lengths after every two atoms of the open-ring sulfur as discussed above, consequently producing the diradical $S_{2}$. It is therefore proposed that the cyclic octasulfur $S_{8}$ and the diradical $S_{2}$ are among major species reacting with alkenes.

The model reactions between the octasulfur and cis-2butene leading to cyclic OPs (addition products) or linear hydropolysulfanes (substitution products), uncovered that only the direct addition of $\mathrm{S}_{8}$ to the double bound appeared to be thermodynamically favourable (Scheme 2). Considering the dominating heterolytic dissociation of the octasulfur ring, it is likely that the addition occurs with formation of the intermediate zwitterion via polar mechanism, as demonstrated in Scheme 2. Interestingly, the initial adduct can favourably react with another molecule of cis-2-butene forming different OPs (Scheme 2). Possibly, these transformations take place through the S-S bond dissociation of the cyclic adduct; however, the exact mechanism (ionic or free-radical) remains to detail.

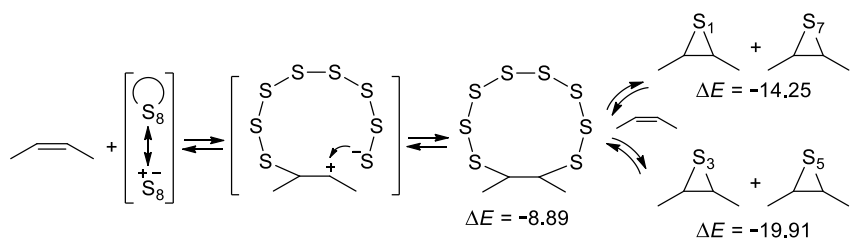

Scheme 2. Proposed addition of the octasulfur to cis-2-butene

It is further established that the disulfur diradical can substitute allyl hydrogens forming linear hydropolysulfanes. This process explains the origin of the substitution reaction that likely occurs via free-radical mechanism and apparently involves cis-trans isomerisation into a more stable trans-derivative (Scheme 3). The cis-trans isomerism in sulfuration processes was earlier shown by IR spectroscopy and this correlates with the current theoretical data $[3,10]$. Because hydropolysulfanes are rather reaction intermediates that are not usually detected among sulfuration products, it is further predicted their transformation into final OPs. Herein, the formation of polysulfanes is hypothesised by the addition of the intermediate hydropolysulfane to cis-2-butene (analogous to thiolene reaction), or by its oxidation with molecular oxygen (Scheme 3). The latest process is particularly favoured and also explains the formation of water, noted earlier for the sulfuration of fatty acid derivatives [19]. It is likely that such transformations serve for the crosslinking between organic chains of alkenes during vulcanisation. 


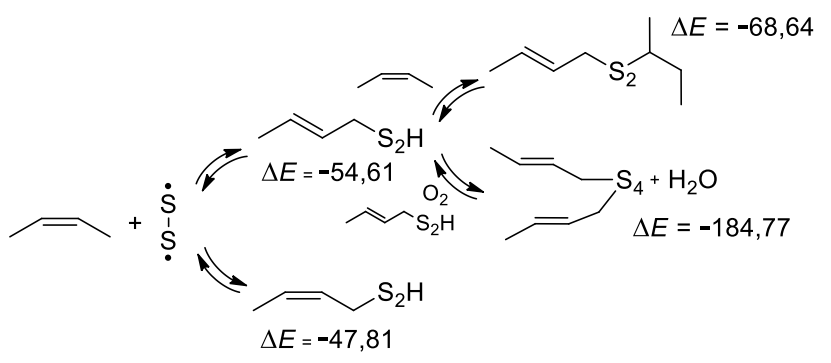

Scheme 3. Proposed substitution of allyl hydrogens of cis-2butene by the disulfur diradical and further transformations into polysulfanes

\section{Conclusions}

This theoretical work provides new insights into the mechanism of sulfur vulcanisation. It does not propose or support a certain polar or free-radical mechanism; instead, it shows that both polar and free-radical reactions are possible. The study uncovers that heterolytic dissociation of the octasulfur ring into the zwitter-ion is thermodynamically more favourable relative to analogous homolysis into diradicals. It is shown that the sulfur zwitterion forms an adduct with cis-2-butene, explaining earlier observed addition to double bonds during the sulfuration. On the other hand, the work defines the formation of the disulfur diradical as a byproduct of the pseudoreversible conversion of the polymeric sulfur into the stable octasulfur form. The computations suggest that the diradical can substitute allyl hydrogens forming hydropolysulfanes, from which OPs may be further generated by the addition reaction or by the oxidation with molecular oxygen.

\section{Literature}

1. Chung W.J., Griebel J.J., Kim E.T., Yoon H., Simmonds A.G., Ji H.J., Dirlam P.T., Glass R.S., Wie J.J., Nguyen N.A., Guralnick B.W., Park J., Somogyi Á., Theato P., Mackay M.E., Sung Y.-E., Char K., Pyun J. The use of elemental sulfur as an alternative feedstock for polymeric materials. Nat. Chem. 2013. 5. 518-524.

2. Бодачівський Ю.С., Поп Г.С. Синтез органосульфанів - поліфункціональних додатків до мастильних матеріалів. Катализ и нефтехимия. 2017. 26. 12-25.

3. Bodachivskyi Yu.S., Pop G.S. Synthesis and structure of sulfur-containing antifriction additives for lubricants. Катализ и нефтехимия. 2014. 23. 15-20.

4. Bodachivskyi I.S., Pop G.S. Designing and characterization of aqueous microemulsions for metalworking operations. Катализ и нефтехимия. 2016. 25. 1-4.

5. Bodachivskyi I., Pop G., Zheleznyi L., Zubenko S., Okhrimenko M. Oleochemical synthesis of sulfanes, their structure and properties. Chem. Chem. Technol. 2017. 11. 365-371.

6. Lim J., Cho Y., Kang E.H., Yang S., Pyun J., Choi T.L., Char K. A one-pot synthesis of polysulfane-bearing block copolymer nanoparticles with tunable size and refractive index. Chem. Commun. 2016. 52. 2485-2488.

7. Zhou D., Chen Y., Li B., Fan H., Cheng F., Shanmukaraj D., Rojo T., Armand M., Wang G. A stable quasi-solid-state sodium-sulfur battery. Angew. Chem. Int. Ed. 2018. 57. 10168-10172.

8. Steudel R. Liquid sulfur. Elemental sulfur and sulfur-rich compounds I. Berlin, Heidelberg: Springer, 2003. 81-116.

9. Бодачівський Ю.С., Поп Г.С., Рогальський С.П. Вплив активаторів на сульфурування естерів вищих жирних кислот олій. Катализ и нефтехимия. 2015. 24. 41-46.

10. Бодачівський Ю.С., Поп Г.С., Головченко О.В. Синтез сульфуровмісних додатків до мастильних матеріалів на основі етилових естерів вищих жирних кислот. Journal of Chemistry and Technologies. 2016. 24. 62-72.

11. Farmer, E.H., Shipley, F.W. 298. The reaction of sulphur and sulphur compounds with olefinic substances. Part I. The reaction of sulphur with mono-olefins and with $\Delta$ 1: 5-diolefins. J. Chem. Soc. 1947. 1519-1532.

12. Ross G.W. 580. The reaction of sulphur and sulphur compounds with olefinic substances. Part X. The kinetics of the reaction of sulfur with cyclohexene and other olefins. J. Chem. Soc. 1958. 2856-2866.

13. Bateman L., Moore C.G., Porter M. 581. The reaction of sulphur and sulphur compounds with olefinic substances. Part XI. The mechanism of interaction of sulphur with mono-olefins and 1 : 5-dienes. J. Chem. Soc. 1958. 2866-2879.

14. Akiba M., Hashim A.S. Vulcanization and crosslinking in elastomers. Prog. Polym. Sci. 1997. 22. 475-521.

15. Nieuwenhuizen P.J., Ehlers A.W., Haasnoot J.G., Janse S.R., Reedijk J., Baerends E.J. The mechanism of zinc(II)-dithiocarbamate-accelerated vulcanization uncovered; theoretical and experimental evidence. J. Am. Chem. Soc. 1999. 121. 163-168.

16. Frisch M.J., et al. Gaussian 09 (Revision D.01). Wallingford CT: Gaussian Inc., 2009.

17. Peter L. Density functional calculations on homonuclear polysulfur ring molecules $\mathrm{S}_{5}-\mathrm{S}_{16}$. Phosphorus, Sulfur Silicon Relat. Elem. 2001. 168. 287-290.

18. Jones R.O., Ballone P. Density functional and Monte Carlo studies of sulfur. I. Structure and bonding in $S_{n}$ rings and chains $(n=2-18) . J$. Chem. Phys. 2003. 118. 9257-9265.

19. Бодачівський Ю.С. Синтез, властивості й застосування олеохімічних полісульфанів: дисертації на здобуття наукового ступеня кандидата хімічних наук / Інститут біооорганічної хімії та нафтохімії ім. В.П. Кухаря НАН України. Київ, 2018.

\section{References}

1. Chung W.J., Griebel J.J., Kim E.T., Yoon H., Simmonds A.G., Ji H.J., Dirlam P.T., Glass R.S., Wie J.J., Nguyen N.A., Guralnick B.W., Park J., Somogyi Á., Theato P., Mackay M.E., Sung Y.-E., Char K., Pyun J. The use of elemental sulfur as an alternative feedstock for polymeric materials. Nat. Chem. 2013. 5. 518-524. 
2. Bodachivskyi I.S., Pop G.S. Synthesis of organosulfanes - multigrade lubricant additives. Kataliz $i$ neftehimiâ. 2017. 26. 12-25. [In Ukrainian]

3. Bodachivskyi Yu.S., Pop G.S. Synthesis and structure of sulfur-containing antifriction additives for lubricants. Kataliz i neftehimiâ. 2014. 23. C. 15-20.

4. Bodachivskyi I.S., Pop G.S. Designing and characterization of aqueous microemulsions for metalworking operations. Kataliz i neftehimiâ. 2016. 25. 1-4.

5. Bodachivskyi I., Pop G., Zheleznyi L., Zubenko S., Okhrimenko M. Oleochemical synthesis of sulfanes, their structure and properties. Chem. Chem. Technol. 2017. 11. 365-371.

6. Lim J., Cho Y., Kang E.H., Yang S., Pyun J., Choi T.L., Char K. A one-pot synthesis of polysulfane-bearing block copolymer nanoparticles with tunable size and refractive index. Chem. Commun. 2016. 52. 2485-2488.

7. Zhou D., Chen Y., Li B., Fan H., Cheng F., Shanmukaraj D., Rojo T., Armand M., Wang G. A stable quasi-solid-state sodium-sulfur battery. Angew. Chem. Int. Ed. 2018. 57. 10168-10172.

8. Steudel R. Liquid sulfur. Elemental sulfur and sulfur-rich compounds I. Berlin, Heidelberg: Springer, 2003. 81-116.

9. Bodachivskyi Yu.S., Pop G.S., Rogalskyi S.P. Effect of accelerators on oil higher fatty acid esters sulfurization. Kataliz i neftehimiâ. 2015. 24. 41-46. [In Ukrainian]

10. Bodachivskyi I.S., Pop G.S., Golovchenko O.V. Synthesis of sulfur-containing lubricant additives on the basis of fatty acid ethyl esters. Journal of Chemistry and Technologies. 2016. 24. 62-72. [In Ukrainian]

11. Farmer, E.H., Shipley, F.W. 298. The reaction of sulphur and sulphur compounds with olefinic substances.
Part I. The reaction of sulphur with mono-olefins and with $\Delta$ 1: 5-diolefins. J. Chem. Soc. 1947. 1519-1532.

12. Ross G.W. 580. The reaction of sulphur and sulphur compounds with olefinic substances. Part X. The kinetics of the reaction of sulfur with cyclohexene and other olefins. J. Chem. Soc. 1958. 2856-2866.

13. Bateman L., Moore C.G., Porter M. 581. The reaction of sulphur and sulphur compounds with olefinic substances. Part XI. The mechanism of interaction of sulphur with mono-olefins and 1 : 5-dienes. J. Chem. Soc. 1958. 2866-2879.

14. Akiba M., Hashim A.S. Vulcanization and crosslinking in elastomers. Prog. Polym. Sci. 1997. 22. 475-521.

15. Nieuwenhuizen P.J., Ehlers A.W., Haasnoot J.G., Janse S.R., Reedijk J., Baerends E.J. The mechanism of zinc(II)-dithiocarbamate-accelerated vulcanization uncovered; theoretical and experimental evidence. J. Am. Chem. Soc. 1999. 121. 163-168.

16. Frisch M.J., et al. Gaussian 09 (Revision D.01). Wallingford CT: Gaussian Inc., 2009.

17. Peter L. Density functional calculations on homonuclear polysulfur ring molecules $\mathrm{S}_{5}-\mathrm{S}_{16}$. Phosphorus, Sulfur Silicon Relat. Elem. 2001. 168. 287-290.

18. Jones R.O., Ballone P. Density functional and Monte Carlo studies of sulfur. I. Structure and bonding in $\mathrm{S}_{n}$ rings and chains $(n=2-18)$. J. Chem. Phys. 2003. 118. 9257-9265.

19. Bodachivskyi I.S. Synthesis, properties, and application of oleochemical polysulfanes: dissertation to receive a scientific degree of Candidate of Chemical Sciences. V.P. Kukhar Institute of Bioorganic Chemistry and Petrochemistry of the National Academy of Sciences of Ukraine. Kyiv, 2018. [In Ukrainian]

Надійшла до редакції 26.01.2020 p. 


\title{
Нове бачення механізмів сіркової вулканізації: теоретичне дослідження
}

\author{
Юрій Бодачівський \\ Сіднейський технологічний університет, \\ Кафедра математичних та фізичних наук, \\ Сідней, Новий Південний Уельс 2007, Австралія \\ E-mail: iurii.bodachivskyi@uts.edu.au
}

\begin{abstract}
Сіркова вулканізація алкенів $€$ важливим промисловим хімічним процесом для синтезу низки органічних полісульфанів як основних продуктів реакцій. Незважаючи на практичне значення, фундаментальне розуміння термічно активованої вулканізації без активаторів $\epsilon$ дещо обмеженим. Насамперед, цей процес $€$ неселективним, що сугтєво ускладнює вивчення механізмів супроводжуючих реакцій, які можугь буги як іонними так і вільнорадикальними. В представленій роботі розглянуго механізми сіркової вулканізації без активаторів із використанням теоретичних методів на рівні B3PW91/6-311+G(3d,f) в симульованій реакційній системі за температури полімеризації сульфуру (432,15 К). Найперше досліджено механізми гомолітичної та гетеролітичної дисоціації циклічного октасульфуру та його перетворення в інші реакційні форми. Передбачено, що гетероліз у цвіттер-іони $є$ основною реакцією порівняно до гомолізу у дирадикали, а також що формування макроциклічних похідних є більш ймовірним ніж аналогічних лінійних форм. Однак, встановлено також можливе утворення дирадикалів дисульфуру як продуктів псевдо-зворотного розкладання високомолекулярного сульфуру у восьмичленну форму. Проаналізовано також модельні реакції сульфуру та иис-2-бутену за подвійними зв'язками та алільними гідрогенами та запропоновано їхні основні напрямки. Ймовірно, що продукти приєднання угворюються за реакцією октасульфуру та алкену через утворення проміжних цвіттер-іонів. Натомість дирадикали дисульфуру можуть заміщувати алільні гідрогени із формуванням гідродисульфанів, які в подальшому перетворюються в полісульфани через приєднання за подвійними зв'язками або окисненням молекулярним киснем.
\end{abstract}

Ключові слова: елементний сульфур, алкени, вулканізація, механізми реакцій 